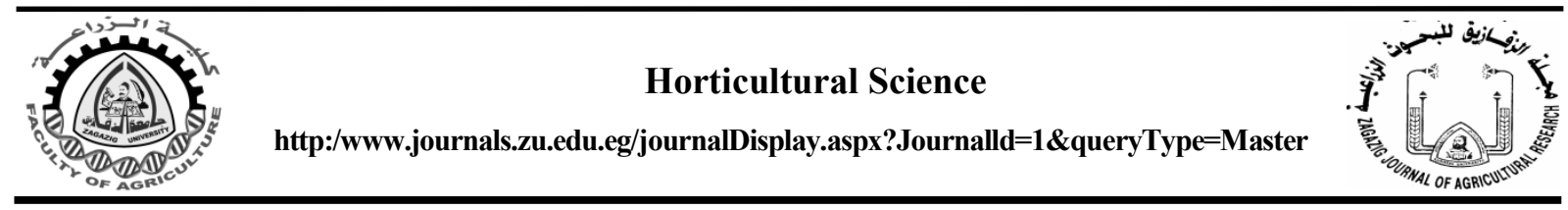

\title{
FLORAL CHARACTERS OF GERBERA (Gerbera jamesonii) AS AFFECTED BY FOLIAR APPLICATION OF HUMIC ACID AND CALCIUM CHLORIDE
}

\author{
Rana M. Jawad* and B.H. Majeed \\ Hort. and Landscape Dept., Coll. Agric., Baghdad Univ., Iraq
}

Received: 19/02/2017 ; Accepted: 27/02/2017

\begin{abstract}
This study was conducted in lath house, Horticultural Department, College of Agriculture, University of Baghdad- Jadriya, Iraq during the spring and fall seasons of 2015 to investigate the influence of foliar application of humic acid and calcium chloride on "Yanara" gerbera cultivar. This study included two factors; humic acid spray $(\mathrm{H})$ and calcium chloride spray $(\mathrm{Ca})$. The first factor was represented by four levels which were; $0\left(\mathrm{H}_{0}\right), 5\left(\mathrm{H}_{5}\right), 7.5\left(\mathrm{H}_{7.5}\right)$ and $10 \mathrm{mll}^{-1}\left(\mathrm{H}_{10}\right)$ and four levels of calcium chloride; $0\left(\mathrm{Ca}_{0}\right), 50\left(\mathrm{Ca}_{50}\right), 100\left(\mathrm{Ca}_{100}\right)$ and $150 \mathrm{mg} .1^{-1}\left(\mathrm{Ca}_{150}\right)$. Data were recorded during spring and fall seasons. The experimental results showed that spraying plants with humic acid at $10 \mathrm{ml}^{-1}$ and calcium chloride at $150 \mathrm{mg} . \mathrm{l}^{-1}\left(\mathrm{H}_{10} \mathrm{Ca}_{150}\right)$ gave the highest values of flower number/plant (3.60 and 6.87), flower diameter (8.71 and $11.33 \mathrm{~cm})$, vase life (11.90 and 11.34 day) for both seasons, respectively. The lowest values of these parameters were recorded with control treatment $\left(\mathrm{H}_{0} \mathrm{Ca}_{0}\right)$. It could be concluded that spraying plants with humic acid at $\mathrm{H}_{10}$ and calcium chloride at $\mathrm{Ca}_{150}$ had improved flower characteristics in gerbera plant cv. Yanara.
\end{abstract}

Key words: Floral characters, gerbera, foliar application, humic acid, calcium chloride.

\section{INTRODUCTION}

Gerbera (Gerbera jamesonii) belongs to family Asteraceae and has 40 species scattered from Africa to Madagascar into tropical Asia and South America. Gerbera is popular plant for the backyard and their daisy-like bloom make ongoing cut flora (Gowda and Srinivasa, 2009). The leaves are elongated, slim and covered with hair (pubescent) underneath, up to 10 inch lengthy and 4 inch broad (Tjia et al., 2008). Gerbera flora computes 4 to 7 inch transversely and can be fair or tinted lenses of yellow, carroty, crimson or scarlet. The midpoint (eye) of the flower can be green, brown, black or dark red. There are five diverse flora forms primarily base on the rows of petals and how they lie on top: solitary, twice or duplex, crested doubles, full crested doubles and quelled crested doubles (Clay, 1983).

Humic based fertilizers and mineral contents are the excellent combination which provides

\footnotetext{
* Corresponding author: Tel. : 009647723556478

E-mail address: ranamousa@yahoo.com
}

the ideal environmental condition for plant growth and development (Dorer and Peacock, 1997). The use of humic acid (HA) is a promising natural resource to be utilized as an alternative for increasing crop production. Humic acids make important contributions to improve soil stability, fertility, improves flower quality that lead to exceptional plant growth and micronutrient uptake (Calvo et al., 2014). Nikbakht et al. (2008) studied the exogenous effect of humic acid on flower characteristics and vase life of gerbera flower. Humic acid also improved NPK concentrations, flower quality, flower diameter and flower longevity. Higher humic acid levels prolong the vase life of gerbera flowers.

Calcium is an essential element as well as a crucial regulator of growth and development in plants. It is present in cell walls, so its role relates to cell wall firmness which results in increased disease resistance. It also plays a role 
in developing lateral buds and in meristems with concurring mitoses (Tobias et al., 1992). Calcium treatment causes a delayed protein and phospholipids reduction off the cell membrane; and increases the ATP activity in petals (Malakooti, 2001). Previous studies emphasized the beneficial effects of calcium spray on floral characters and vase life of gerbera flower (Attoa, 2008; Andreasen et al., 2014; Deljou and Gholipour, 2014).

The target of this study was to evaluate floral characters and vase life of "Yanara" gerbera cultivar as affected by foliar application of humic acid and calcium under Iraq conditions.

\section{MATERIALS AND METHODS}

This study was conducted in the lath house, Horticultural Department, College of Agriculture, University of Baghdad- Jadriya, Iraq during the spring and fall seasons of 2015 to investigate the influence of humic acid and calcium chloride foliar application on "Yanara" gerbera cultivar. This study included two factors; humic acid spray $(\mathrm{H})$ and calcium chloride spray (Ca). The first factor was represented by four levels i.e.; $0\left(\mathrm{H}_{0}\right), 5\left(\mathrm{H}_{5}\right), 7.5$ $\left(\mathrm{H}_{7.5}\right)$ and $10 \mathrm{ml}^{-1} \mathrm{l}^{-1}\left(\mathrm{H}_{10}\right)$ while calcium chloride was included four levels i.e. $0\left(\mathrm{Ca}_{0}\right), 50\left(\mathrm{Ca}_{50}\right)$, $100\left(\mathrm{Ca}_{100}\right)$ and $150\left(\mathrm{Ca}_{150}\right) \mathrm{mg} \cdot \mathrm{l}^{-1}$. The statistical layout of this experiment was randomized complete block design. Each treatment was replicated three times. Each replicate contained five plants.

At full flowering stage the following measurements were recorded: number of flowers, flower diameter $(\mathrm{cm})$, length of the flower stalk $(\mathrm{cm})$, fresh weight of flowers and stalk $(\mathrm{g})$ and dry weight of flowers and stalk (g), vase life (day) was determined with visible wilting of petals and their rolling to the outer part (Safa et al., 2012). Data were recorded during spring and fall seasons.

The obtained data were subjected to analysis of variance according to Elsahookie and Wuhaib
(1990) using LSD for comparing differences between various treatment means.

\section{RESULTS AND DISCUSSION}

\section{Effects of Humic acid and Calcium on Number of Flowers, Flower Dameter and Length of the Flower Stalk}

As shown in Table 1 the maximum number of flowers/plant during spring season were belonged to the combination between the highest humic acid concentration $\left(\mathrm{H}_{10}\right)$ and medium $\left(\mathrm{Ga}_{50}\right)$ or high $\left(\mathrm{Ca}_{100}\right)$ concentrations of calcium, without significant difference between both treatments. Moreover, during fall season, the interaction treatments between the highest concentration of humic acid and all applied calcium levels gave the ultimate numbers of flowers, without significant differences among these treatments. It is worth to mention that number of flowers produced during fall season surpassed those obtained during spring season. The largest flower diameter $(8.71$ and $11.33 \mathrm{~cm})$ were produced during spring and fall seasons, respectively. Concerning flower stalk length, it was observed that the tallest flowers were belonged to the combination treatments between the highest concentration of humic acid $\left(\mathrm{H}_{10}\right)$ and different calcium levels during either spring or fall seasons.

These results are in parallel with those of Mazhar et al. (2012) who studied the effect of four concentrations of humic acid $(0,1,1.5$ and $2 \%$ ) used as a foliar spray on flower parameters of chrysanthemum plant and found that humic acid $(2 \%)$ gave a significant increase in flower number. Also these results are in harmony with those obtained by Pradeep et al. (2014) on gladiolus, and Palanisamy et al. (2015) on gerbera plants. Also these results are in harmony with those obtained by (Attoa, 2008 ; Deljou and Gholipour, 2014) who studied the effect of calcium spray on flower characters of gerbera plants. 
Zagazig J. Agric. Res., Vol. 44 No. (3) 2017

Table 1. Effects of foliar application of humic acid and calcium on number of flowers/plant, flower diameter and length of Yanara gerbera cultivar during spring and autumn seasons

\begin{tabular}{|c|c|c|c|c|c|c|c|}
\hline \multirow[t]{2}{*}{$\begin{array}{l}\text { Humic acid } \\
\left(\left(\mathrm{ml} . \mathrm{I}^{-1}\right)\right.\end{array}$} & \multirow{2}{*}{$\begin{array}{c}\text { Calcium } \\
\text { chloride } \\
\left(\mathrm{mg.l}^{-1}\right)\end{array}$} & \multicolumn{2}{|c|}{$\begin{array}{c}\text { Number of } \\
\text { flowers/plant }\end{array}$} & \multicolumn{2}{|c|}{$\begin{array}{l}\text { Flower diameter } \\
(\mathrm{cm})\end{array}$} & \multicolumn{2}{|c|}{$\begin{array}{c}\text { Flower stalk length } \\
(\mathrm{cm})\end{array}$} \\
\hline & & Spring & Fall & Spring & Fall & Spring & Fall \\
\hline \multirow{4}{*}{ 0 } & 0 & 2.60 & 4.27 & 8.42 & 8.50 & 38.11 & 31.44 \\
\hline & 50 & 2.67 & 4.40 & 8.76 & 8.66 & 43.97 & 32.49 \\
\hline & 100 & 2.87 & 4.47 & 8.50 & 8.66 & 45.03 & 34.18 \\
\hline & 150 & 3.07 & 4.47 & 7.65 & 8.87 & 33.89 & 40.16 \\
\hline \multirow{4}{*}{5} & $\mathbf{0}$ & 2.73 & 4.67 & 8.04 & 8.93 & 37.78 & 33.19 \\
\hline & 50 & 2.93 & 5.47 & 8.14 & 9.15 & 37.84 & 35.78 \\
\hline & 100 & 2.73 & 5.20 & 8.01 & 10.23 & 39.51 & 40.22 \\
\hline & 150 & 3.20 & 5.53 & 8.33 & 10.54 & 41.46 & 42.37 \\
\hline \multirow{4}{*}{7.5} & 0 & 2.87 & 5.27 & 7.79 & 9.67 & 34.04 & 34.95 \\
\hline & 50 & 3.07 & 5.80 & 8.08 & 9.99 & 41.25 & 37.88 \\
\hline & 100 & 3.20 & 6.07 & 8.19 & 10.45 & 40.04 & 42.90 \\
\hline & 150 & 3.33 & 6.27 & 8.52 & 10.86 & 40.88 & 44.87 \\
\hline \multirow{4}{*}{10} & $\mathbf{0}$ & 3.00 & 6.07 & 8.54 & 10.26 & 42.72 & 37.91 \\
\hline & 50 & 3.27 & 6.33 & 8.57 & 10.53 & 44.01 & 40.82 \\
\hline & 100 & 3.40 & 6.60 & 8.52 & 10.07 & 41.63 & 45.13 \\
\hline & 150 & 3.60 & 6.87 & 8.71 & 11.33 & 42.20 & 47.78 \\
\hline LSD 5\% & & 0.26 & 0.74 & 0.22 & 0.78 & 2.33 & 6.46 \\
\hline
\end{tabular}

Effects of Humic Acid and Calcium on Fresh and Dry Weights of Flowers and Stalk and Vase Life

Results presented in Table 2 show that however during spring season there was no significant difference between control treatment and many of applied treatments concerning flower fresh weight, the highest fresh weight of flower was obtained during fall season by spraying plant with the highest concentration of both humic acid $\left(10 \mathrm{ml} . \mathrm{l}^{-1}\right)$ and calcium chloride $\left(150 \mathrm{mg} \mathrm{l}^{-1}\right)$. Dry weight of flower did not significantly affected by spraying plants with either humic acid or calcium chloride at any applied concentration. Vase life of flowers was significantly extended by treating plants with high concentration of humic acid combined with medium or high concentrations of calcium chloride. These treatments gave the maximum vase life during spring season without significant difference between both treatments. Meanwhile, during fall season the highest vase life values were recorded by treating plants with the medium or high levels of calcium chloride either alone or combined with different concentrations of humic acid without significant differences among these treatments in most cases.

This result is consistent with the findings of Nabigol (2012) on rose plants; Andreasen et al. (2015) on gerbera plants and Ali et al. (2015) on tulip plants. 
Table 2. Effect of foliar application of humic acid and calcium on fresh and dry weights and vase life of Yanara gerbera cultivar flowers during spring and fall seasons

\begin{tabular}{|c|c|c|c|c|c|c|c|}
\hline \multirow[t]{2}{*}{$\begin{array}{l}\text { Humic acid } \\
\left(\mathrm{mll}^{-\mathrm{I}^{-1}}\right)\end{array}$} & \multirow{2}{*}{$\begin{array}{c}\text { Calcium } \\
\text { chloride } \\
\left(\mathrm{mg}^{-1} \mathrm{l}^{-1}\right)\end{array}$} & \multicolumn{2}{|c|}{$\begin{array}{c}\text { Fresh weight of flowers } \\
\text { and stalk (g) } \\
\end{array}$} & \multicolumn{2}{|c|}{$\begin{array}{c}\text { Dry weight of flowers } \\
\text { and stalk (g) }\end{array}$} & \multicolumn{2}{|c|}{$\begin{array}{l}\text { Vase life } \\
\text { (day) }\end{array}$} \\
\hline & & Spring & Fall & Spring & Fall & Spring & Fall \\
\hline \multirow{4}{*}{ 0 } & $\mathbf{0}$ & 13.82 & 9.83 & 1.48 & 1.27 & 9.11 & 9.74 \\
\hline & 50 & 13.21 & 11.29 & 1.39 & 1.33 & 9.34 & 10.18 \\
\hline & 100 & 15.11 & 11.32 & 1.29 & 1.34 & 9.47 & 10.50 \\
\hline & 150 & 10.00 & 12.11 & 1.53 & 1.39 & 9.82 & 10.56 \\
\hline \multirow{4}{*}{5} & $\mathbf{0}$ & 11.43 & 11.45 & 1.20 & 1.48 & 9.54 & 9.90 \\
\hline & 50 & 11.50 & 13.15 & 1.26 & 1.41 & 9.95 & 10.27 \\
\hline & 100 & 13.98 & 13.65 & 1.52 & 1.44 & 10.26 & 10.71 \\
\hline & 150 & 13.25 & 14.87 & 1.39 & 1.53 & 10.67 & 10.96 \\
\hline \multirow{4}{*}{7.5} & 0 & 13.11 & 19.25 & 1.45 & 1.57 & 10.02 & 10.07 \\
\hline & 50 & 13.02 & 15.97 & 1.05 & 1.63 & 10.48 & 10.35 \\
\hline & 100 & 12.30 & 16.18 & 1.28 & 1.67 & 10.91 & 10.79 \\
\hline & 150 & 13.21 & 18.33 & 1.17 & 1.70 & 11.05 & 11.12 \\
\hline \multirow{4}{*}{10} & $\mathbf{0}$ & 13.05 & 19.88 & 1.57 & 1.59 & 10.41 & 10.39 \\
\hline & 50 & 16.63 & 20.78 & 1.32 & 10.62 & 10.80 & 10.88 \\
\hline & 100 & 14.23 & 23.92 & 1.06 & 1.60 & 11.66 & 11.18 \\
\hline & 150 & 13.46 & 28.28 & 1.12 & 1.55 & 11.90 & 11.34 \\
\hline LSD 5\% & & 0.92 & 4.04 & N.S & N.S & 0.74 & 0.92 \\
\hline
\end{tabular}

\section{REFERENCES}

Ali, A., S.U. Rehman, S.U. Allah and S. Raza (2015). Combined effect of humic acid and NPK on growth and flower development of Tulipa gesneriana in Faislabad, Pak. IJAVMS, 9 (1): 18-28.

Andreasen, C., A.H. Kemezys and R. Müller (2014). The effect of fertilizer level and foliar-applied calcium on seed production and germination of Gerbera hybrida. Hort. Sci., 49 (5): 538-543.

Attoa, G.E. (2008). Response of gerbera to mineral fertilizers irrigation intervals and growth retardants. Ann. Agric. Sci., Moshtohor, 46 (1): 21-30.

Calvo, P., L. Nelson and J.W. Kloepper (2014). Agricultural uses of plant biostimulants. Plant Soil, 383 : 3- 41.

Clay, H. (1983). Gerberas. Georgia Coop. Ext. Serv. Lft L., 368.

Deljou, N.M.J. and K. Gholipour (2014). Effect of pre and post anthesis foliar application of calcium on postharvest quality of gerbera cut flower. Acta Hort., 1034: 539-543.

Dorer, S.P and C.H. Peacock (1997). The effects of humate and organic fertilizer on establishment and nutrition of creeping bent 
putting greens. Int. Turfgrass. Soc. Res. J., 8: 437-444.

Elsahookie, M.M. and K.M. Wuhaib (1990). Design and Analysis of Experiments. Bagh Univ., Dar Al Hekma.

Gowda, M. and V. Srinivasa (2009). Hi-Tech Floriculture in Karnataka. Occasional paper$94: 1-163$.

Malakooti, M.J. (2001). Why calcium spray in fruit trees should be common. Jahad Keshavarsy Embassy. Hort. Sec., 273-283.

Mazhar, A.A.M., S.I. Shedeed, N.G. Abdel-Aziz and M.H. Mahgoub (2012). Growth, flowering and chemical constituents of Chrysanthemum indicum L. plant in response to different levels of humic acid and salinity. J. Appl. Sci. Res., 8(7): 3697-3706.

Nabigol, A. (2012). Pre-harvest calcium sulfate application improves postharvest quality of cut rose flowers. Afr. J. Biotechnol., 11 (5): 1078-1083.

Nikbakht, A., K. Mohsen, B. Mesbah, X.Y. Ping, L. Ancheng and E. Nemat-Allah (2008). Effect of humic acid on plant growth, nutrient uptake and postharvest life of Gerbera. J. Plant Nut., 31: 2155-2167.
Palanisamy, K.D., R. Sharma. S.S. Bhatt and A. Singh (2015). Fertigation Studies on Gerbera (Gerbera jamesonii Bolus Ex Hooker F.) for growth and yield under cover in southern hills (Shevaroy). Int. J. Tropical Agric., 33 (1): 31-36.

Pradeep, K., K. Manivannan and S.R, Kumar (2014). Effect of organic nutrients on growth, flowering and yield of Gladiolus grandiflorus L. Asian J. Hort., 9 (2):416-420.

Safa, Z., D. Hashemabadi and B. Kaviani (2012). Improving the vase life of cut Gerbera (Gerbera jamesonii L. cv. 'Balance') flower with silver nano-particles. Europ. J. Exp. Biol., 2 (6): 2489-2492.

Tjia, B., R.J. Black and S. Park-Brown (2008). Gerberas for Florida. CIR527. Gainesville: University of Florida Institute of Food and Agricultural Sciences. http://edis. ifas. ufl. edu/ mg034.

Tobias, R.B., W.S. Conway, C.E. Sams, K.C. Gross and B.D. Whitaker (1992). Cell wall composition of calcium treated apples inoculated with Botrytis cinerea. Phytochem, 32 (1): 35- 39.

\section{تأثير الإضافة الورقية لحمض الهيوميك وكلوريد الكالسيوم على الخصائص الزهرية لنبات الجيربيرا}

$$
\begin{aligned}
& \text { رنا موسى جواد - بيان حمزه مجيد } \\
& \text { قسم البستخة وهنسة الحدائق ـ كلية الزراعة ـ جامعة بغداد ـ العراق }
\end{aligned}
$$

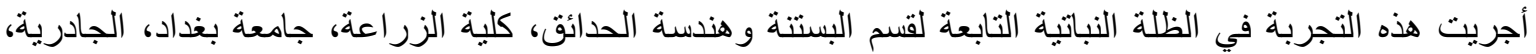

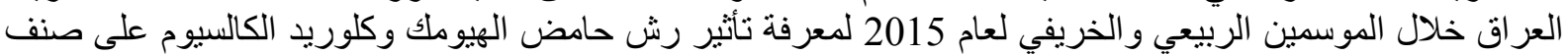

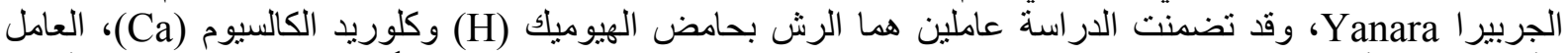

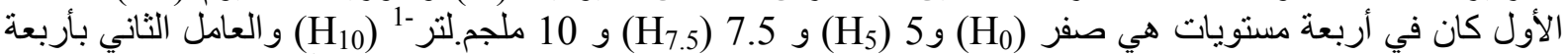

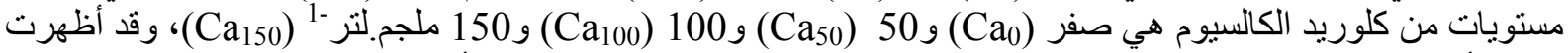

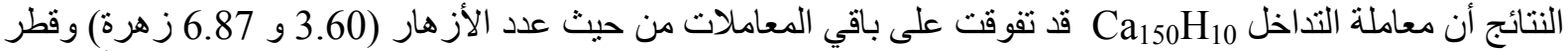

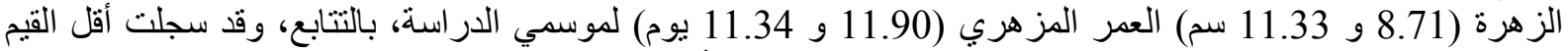

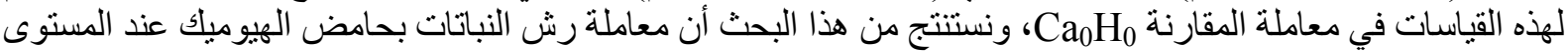

وكلوريد الكالسيوم عند المستوى Ca $\mathrm{H}_{150}$ قد أدت إلى تحسين الصفات الزهرية في نباتات الجربير ا صنف Yanara. 